\title{
Concrete Tensile Strength Test Using Different Sand Gradation Zones to Mitigate Earthquake Buildings
}

\author{
Fepi Supriani ${ }^{1}$, Mukhlis Islam ${ }^{1, *}$ and Yuzuar Afrizal ${ }^{1}$ \\ 'Department of Civil Engineering, Faculty of Engineering, Universitas Bengkulu, Kota Bengkulu, 38371A Indonesia.
}

ABSTRACT - Sand is one of the building materials forming the concrete mass. Sand has a type based on quarry sources, namely sea sand, river sand and mountain sand. Sand has different characteristics such as gradations (grain fineness), unit weight, mud content. Based on the SKSNI 03-2834-1993 standard, sand has a grain size which is classified as very rough, rough, medium, smooth and very smooth. Sand that has a good gradation is separated in the form of a graph as zones 1 to 4 . Concrete has good compressive strength but is weak on tensile strength. To increase the tensile strength, fiber can be added. The use of wire fiber is expected to increase the performance of buildings in earthquake-prone areas. In this study the fiber used was metal wire with a length of approximately $2 \mathrm{~cm}$, designed compressive strength of concrete of $25 \mathrm{MPa}$, with a cylindrical sample diameter of $15 \mathrm{~cm}$ and a height of $30 \mathrm{~cm}, 3$ month old age split tensile strength test was conducted, by using sea and mountain river sand with different zones. The results obtained that the division of the sand zone into rough to fine classification does not provide a significant trend for the tensile strength of the concrete. Mechanically, the addition of wire fibers for Air Lakok sand, Lubuk Kebur river sand and Penanding river sand has decreased the tensile strength. While the sea sand of Selubuk, the river sand of Talang Rasau and the mountain sand has increased tensile strength. Visually, all concrete that is given wire fiber has better ductility, where the concrete does not experience brittle cracks and the elements are still bound to each other.

\author{
ARTICLE HISTORY \\ Received: JUN 28, 2021 \\ Revised: OCT 06, 2021 \\ Accepted: OCT 08, 2021
}

\section{KEYWORDS}

Fine aggregate

Aggregate gradation

Wire fiber concrete

Split tensile strength

\section{INTRODUCTION}

The use of sand in infrastructure development has led to the exploitation large quantities of sand. Sand is a limited resource; sand mining cannot be avoided because it must meet the needs of the building's material. Sand has a type and name based on the location of the quarry which includes sea sand, mountain sand and river sand. The condition of the sand is strongly influenced by natural conditions in the region concerned [1]. The province of Bengkulu besides being located on the West coast of Sumatra also has mountainous areas that are crossed by rivers. Based on this strategic location, sand resources can be obtained from the sea, mountains and rivers. As one of the main material for construction, sand must have good characteristics and quality, especially for the development in Bengkulu City, Indonesia which is an earthquake-prone area. Earthquake mitigation in buildings can be done by construct buildings that comply to the standard seismicity.

The characteristics of fine aggregate quality used as concrete structural components play an important role in determining the quality characteristics of the concrete structures produced, because fine aggregates fill up most of the volume of the concrete. Sea sand as one type of fine aggregate material has availability in large quantities [2].

Sand as a building material plays an important role in the strength of building construction. The use of sand with coarse aggregates, cement and water as well as with or without additives is called concrete. Sand has a type and name based on its quarry locations which includes sea sand, mountain sand and river sand. Types from different sources cause sand to have different characteristics. The characteristics of sand include fine grain modulus and gradation, specific gravity, unit weight, mud content and organic content. The characteristics of the sand will likely affect the strength of the construction of the building formed. One of the important characteristics of sand is the grading of grains which are variations of sand grains which can be mapped into a sand zone graph. With the sand zone, it can be seen that the type of sand that covers sand is very rough, rough, medium, smooth and very smooth.

Concrete which is a mixture of cement, sand, coarse aggregates and water forms concrete mass and strength. Concrete has the strength to resist compressive forces, but has the disadvantage of having a low tensile strength which causes the concrete to crack and be brittle. In order to increase the ductility of concrete, it is necessary to use additional materials, namely the addition of material that can increase the tensile strength in the concrete. Addition of fiber to the fresh concrete mixture is one of the efforts to increase the ductility in concrete. In buildings it is expected that the collapse does not occur suddenly, instead can provide a crack mark first, which would happen if the nature of the building is ductile. The use of metal fibers is expected to overcome and remain binding on concrete material under tension stress. 
The tensile strength of concrete is one of the important parameters of concrete strength. The value of split tensile strength is obtained by using splitting tensile test in the laboratory by loading each cylindrical specimen laterally to its maximum strength.

The background of this study is arising from the abundant sand resources in Bengkulu Province which were obtained from different sources or quarries for the construction development in the City of Bengkulu. Sand that has different grain characteristics will be grouped in a sand zone and used for concrete mixture. The addition of metal wire pieces is expected to increase the plasticity or ductility of concrete and is suitable for earthquake-prone areas. The purpose of this study is to determine the effect of sand from different zones in concrete with addition of metal wire pieces towards splitting tensile strength.

\section{LITERATURE AND RESEARCH METHODOLOGY}

Concrete is a function of its constituent material consisting of hydraulic cement (Portland cement), coarse aggregates, fine aggregates, water and added materials (admixture or additive). To study the behavior of combined elements (concrete constituent materials), the information of the characteristics of each component is needed. The selection of appropriate material composition will produce efficient concrete, fulfilling the required boundary strength and meeting serviceability requirements which can also be interpreted as reliable service by meeting economic criteria [3].

Concrete which is added with fiber is called fiber concrete. Fiber can be asbestos, glass, plastic, steel, metal wire, or plant fibers (hemp, palm fiber). Fiber in concrete aims to increase the tensile strength of concrete, due to the very low tensile strength of the concrete. Very low tensile strength of concrete results in easy cracking of concrete, which in turn reduces the durability of concrete [4].

The fibers commonly used are steel fibers, glass fibers, wire fibers, carbon fibers, polyethylene fibers, polypropylene fibers, natural fibers such as hemp and palm fiber, coconut fiber, and others [5]. The strength of the metal wire fiber is its strength and high modulus which can add tensile strength to the concrete, but this fiber also has the disadvantage of being very corrosive. This will be very affective if there is a portion of the fiber that is not protected / covered by concrete, therefore the wire fiber must be completely covered by concrete, so as not to corrode for a long time will affect the concrete itself.

Gradation is a characteristic that shows variations in sand grains. SNI 03-2834-1993 standard [6] divides four zones of sand from fine grained to coarse. Zone I sand being very coarse and zone IV sand is very fine. It is generally recommended by code to use sands of zones I to Zone III for structural concrete works. Varied granules is considered to be more profitable because it can fill each other and form a solid mass.

\section{Split Tensile Strength of Concrete}

The tensile strength of concrete is usually $8-15 \%$ of the compressive strength of concrete. Tensile strength is an important property that affects propagation and the size of cracks in the structure. Split tensile strength is usually determined using a cylindrical loading experiment, where a cylinder of the same size as the test object in the compressive strength is placed on the side of the test machine and the load are applied evenly in the direction of the test specimen diameter [7]. Split tensile strength can be calculated using the following formula:

$$
f_{s p}^{\prime}=\frac{2 P}{\pi D L}
$$

where :

$\mathrm{f}^{\prime}{ }_{\mathrm{sp}}=$ Split tensile strength of concrete $[\mathrm{MPa}]$

$\mathrm{P}=$ maximum loading $[\mathrm{N}]$

$\mathrm{L}=$ specimen length $[\mathrm{mm}]$

$\mathrm{D}=$ specimen diameter $[\mathrm{mm}]$

$\pi=$ Phi (3.14159)

The stages in the research are:

1. Preparation of research materials, procuring sand from different quarries and different zones

2. Test the physical properties of the material, namely

a. Sand gradation check, based on SK SNI 03-1968-1990 standard [8].

b. Examination of mud content from coarse aggregates and sand.

c. Examination of unit weight and specific gravity

3. Design of the composition of planned Concrete Mixes with $25 \mathrm{Mpa}$ compressive strength with a slump value of 60-100 mm. Design of concrete mixtures in this study based on SNI 03-2834-1993 [6]. The concrete mix design is carried out based on the data of the sea sand physical test results with the best zone, which is used as a comparison.

\section{Specimen fabrication for split tensile strength test}

The specimens fabrication was conducted based on SNI 03-2493-2011 standard [9]. The specimens used were cylindrical in size measuring $15 \mathrm{~cm}$ in diameter, $30 \mathrm{~cm}$ in length for testing the tensile strength of concrete. Each type of sand is taken from 4 different sources from several districts / cities in Bengkulu Province. Testing of normal concrete tensile strength 
and the addition of wire fiber were carried out for the original sand (did not experience any treatment) and with washing treatment.

The research was conducted by the following procedure:

a. Making cylindrical specimens $\phi=15 \mathrm{~cm}, \mathrm{t}=30 \mathrm{~cm}$.

b. Examination of slump value from each concrete mixture used is $6-10 \mathrm{~cm}$.

c. Specimens curing

d. Test the concrete tensile strength using a compressive test machine. Testing of concrete tensile strength in this study based on SNI 03-2491-2002 [10]. The test aims to determine the magnitude of the maximum load that can be held by the test object, as shown in Figure 1.

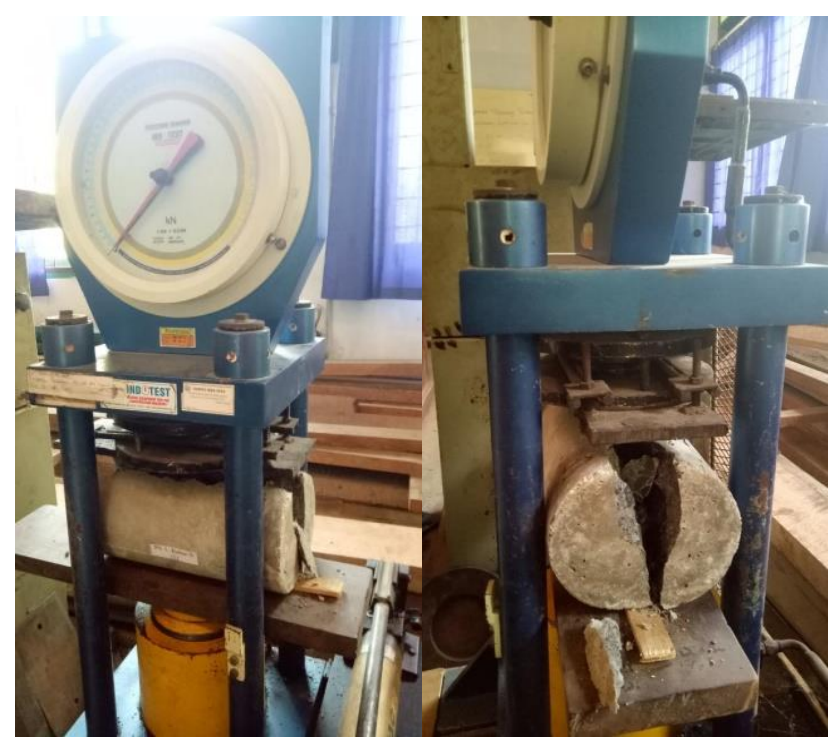

Figure 1. Concrete split tensile strength test

\section{RESULTS AND DISCUSSION}

\section{Mechanical properties / tensile strength of concrete}

The tensile strength of concrete was tested on specimens with a mixture of $2 \mathrm{~cm}$ solid wire pieces weighing $200 \mathrm{~g}$ for 4 specimens, with the treatment of sand both not washed and washed. Comparison is done with normal concrete without the addition of wire fibers. The purpose of wire fiber addition is to see the bonding of wire with the concrete mass formed by cement, sand and coarse aggregates. The use of sand with different zones based on roughness is intended to see the effect of the amount of sand grains on the bond between the concrete forming material and the concrete ductility in general. The results of the split tensile strength test on 3 month old concrete can be seen in Table 1 .

Table 1. Concrete split tensile strength test results

\begin{tabular}{|c|c|c|c|c|}
\hline No & Name of Sand & $\begin{array}{c}\text { Normal } \\
\text { Concrete } \\
(\mathrm{MPa})\end{array}$ & $\begin{array}{l}\text { Concrete with wire fiber } \\
\text { (unwashed sand) (MPa) }\end{array}$ & $\begin{array}{c}\text { Concrete with } \\
\text { wire fiber } \\
\text { (washed sand) } \\
(\mathrm{MPa})\end{array}$ \\
\hline 1 & $\begin{array}{l}\text { Air Lakok Sea Sand } \\
\text { (Zone II) }\end{array}$ & 3.398 & 3.207 & 3.016 \\
\hline 2 & $\begin{array}{l}\text { Selubuk Kasar Sea Sand } \\
\text { (Zone III) }\end{array}$ & 3.028 & 3.068 & 3.066 \\
\hline 3 & $\begin{array}{l}\text { Lubuk Kebur River Sand } \\
\text { (Zone I) }\end{array}$ & 2.642 & 1.927 & 2.691 \\
\hline 4 & $\begin{array}{l}\text { Talang Rasau River Sand } \\
\text { (Zone III) }\end{array}$ & 2.548 & 3.101 & 2.927 \\
\hline 5 & $\begin{array}{l}\text { Penanding River Sand } \\
\text { (Zone III) }\end{array}$ & 2.807 & 2.508 & 2.711 \\
\hline 6 & Mountain Sand (Zone III) & 3.003 & 3.292 & 2.833 \\
\hline
\end{tabular}

Table 1. shows that sea sand has a split tensile strength above $3 \mathrm{MPa}$. rougher sea sand with zone 2 gives greater strength than finer sea sand of zone 3. River sand has a concrete split tensile strength of 2-3 MPa, and by comparing river sand of zone 1 and zone 3 it was obtained that they do not have a significant difference and trend. The mountain sand was categorized as zone 3 with a split tensile strength of $3 \mathrm{MPa}$. The strength is tend to decrease for washed sand with additional wire fibers. 


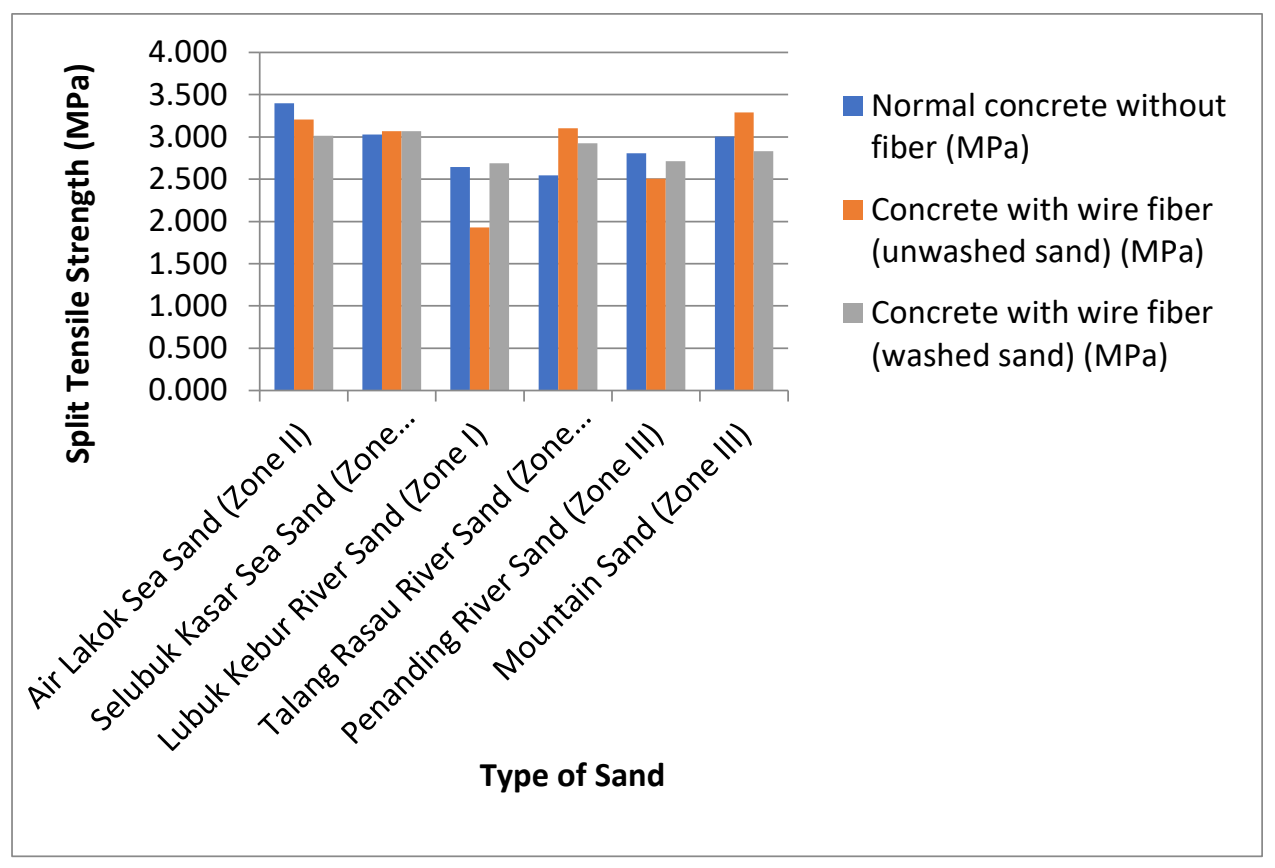

Figure 2. Split tensile strength of concrete

Figure 2 shows that normal concrete using sea sand of Air Lakok has a higher tensile strength compares to the concrete with additional wire fibers using sand that is both washed and not washed sand. Unlike the Selubuk sea sand which has an upward trend for concrete with fiber compares to normal concrete, both for washed and not washed sand .

The Lubuk Kebur and Penanding river sand gives the same trends where the unwashed sand has the lowest tensile strength. The mud content levels on both sands have negative effects on concrete strength. While for the Talang Rasau river sand the mud content of the unwashed sand gives higher strength. Similarly for mountain sand, washed sand instead gives lower strength values of normal concrete compares to non-washed concrete either with or without wire fibers.

From the data of the split tensile strength of concrete, it does not provide a linear trend. Some other unknown variables influence the split tensile strength of concrete. Some concrete with a certain type of sand has a higher tensile strength when added with wire fibers and washed to remove the level of mud that can inhibit the adhesion of the concrete mixture. Likewise, there is a certain type of sand with a higher split tensile strength of concrete without additional wire fibers.

\section{Visually inspected concrete ductility}

Ductility is the ability of structural elements to deform during loading. Ductility in buildings is very important especially for dynamic loading due to earthquakes. Structural elements that have ductility are expected not to experience sudden collapse. The results of visual testing between concrete and different sand zone as follow:

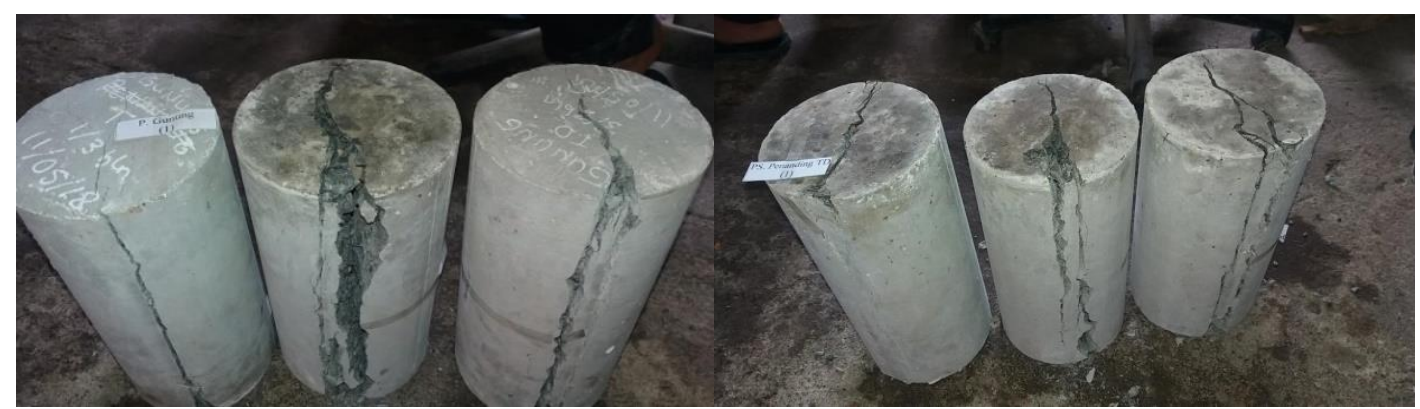

a. Mountain Sand

b. Penanding River Sand

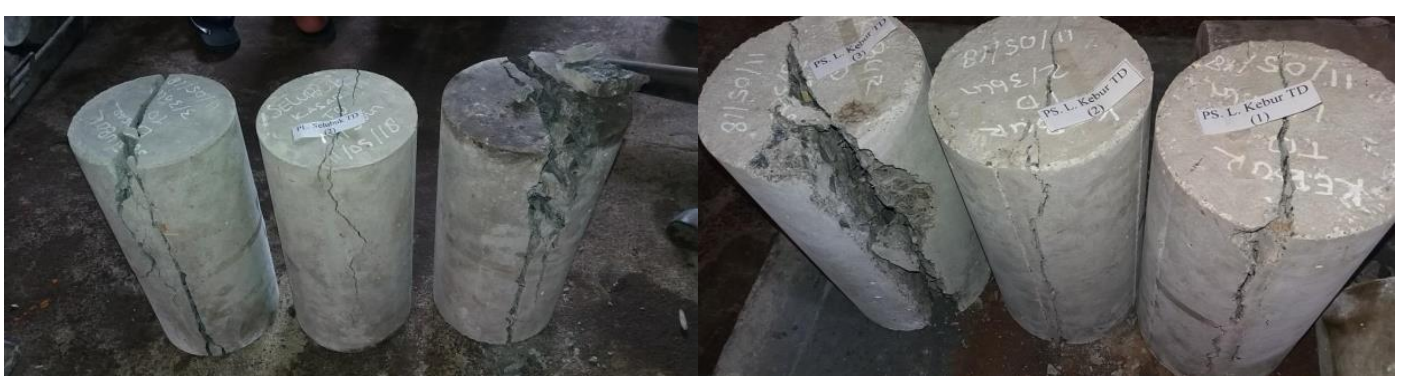

c. Selubuk Sea Sand

d. Lubuk Kebur River Sand

Figure 3. Cracking mode of samples with wire fiber 
By visual inspection the tested specimens show that all the samples using any type of sand was not totally split under maximum loading. The fibers continue to bridge the cracks till total failure occurs. Figure 3 shows that the two parts of the specimens are still attached to each other which are bound by wire fibers. Some samples only sustain cracks instead of total splitting. Unlike the normal concrete without wire fiber as shown in Figure 4, from which it was shown that the concrete samples was totally split and brittle and even some samples experience total destruction. In earthquake-prone areas ductile properties are needed for building elements, collapse that does not suddenly provide an opportunity to save oneself inside the building.

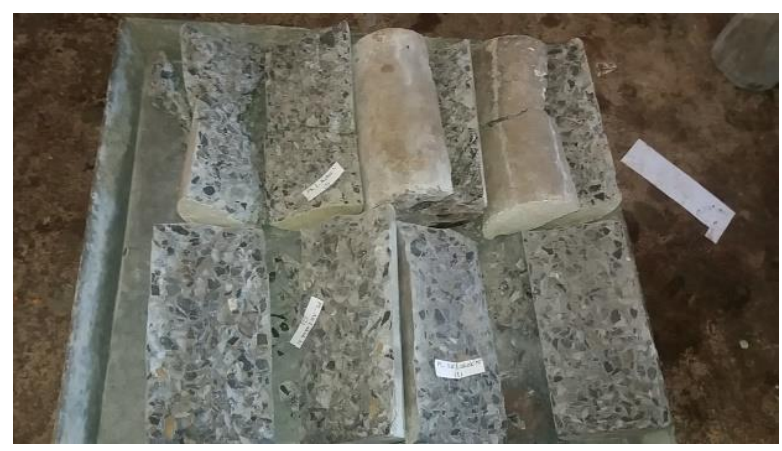

Figure 4. Normal concrete specimen without wire fiber

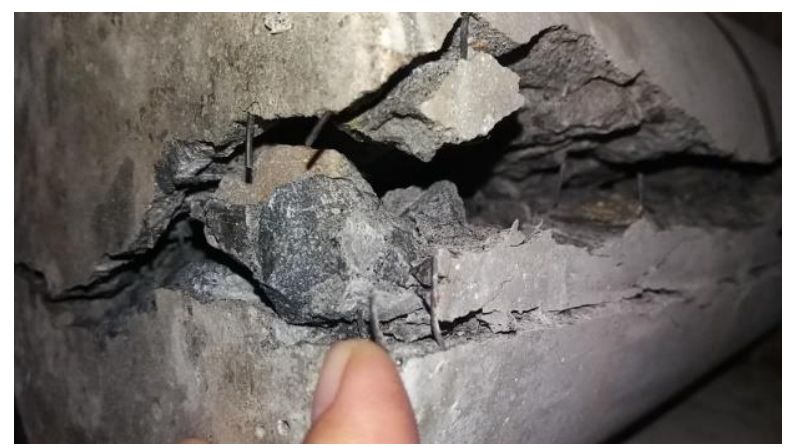

Figure 5. Wire fiber bonding to concrete

Figure 5 shows a wire fiber bond in concrete that gives bond between the elements of the concrete composing material which causes the concrete to become more ductile. The wire fiber that serves as its own fiber is a foreign material in concrete and if the proportion does not fit it can weaken the concrete itself. Table 1 shows the decrease of tensile strength from normal concrete to concrete with wire fibers.

From the test results it is shown that there is no direct relationship between the roughness of the sand granules to the tensile strength of the concrete. This can be seen from the Lubuk Kebur river sand that enters zone I (rough) has a smaller tensile strength compares to sea and mountain sands that are included in zone III (rather smooth). From the results of the testing of split tensile strength it is seen that river sand has a split tensile strength below $3 \mathrm{MPa}$ for normal concrete and concrete with the addition of wire fibers, whereas sea and mountain sands have more than $3 \mathrm{MPa}$ of strength.

\section{CONCLUSION}

1. Classification of coarse to fine sand based on zoning does not show a direct relationship with tensile strength of the concrete

2. Addition of wire fiber for Air Lakok sea sand, Lubuk Kebur river sand and Penanding river sand produce concrete samples with split tensile strength that is lower than normal concrete, while for Selubuk sea sand, Talang Rasau river sand and any mountain sand, wire fiber addition gives higher split tension strength results than normal concrete.

3. Visually, all concrete that is given wire fiber has higher ductility ductility compares to normal concrete.

\section{ACKNOWLEDGEMENT}

This activity is funded by the Ministry of Research, Technology and Higher Education through a national strategic research scheme. Thank you for laboratory staff and assistants who have worked during the laboratory research, Bob Ramosta, Rizki Arian and Habib Anoviandra.

\section{REFERENCES}

[1] Nugraha, P., “Teknologi Beton, Dari Material, Pembuatan, ke Beton Kinerja Tinggi”, Andi Offset, Yogyakarta 
[2] Mangerongkonda, D., "Pengaruh Penggunaan Pasir Laut Bangka Terhadap Karakteristik Kualitas Beton", http://library.gunadarma.ac.id/10399066-jurnal.ftsp.pdf, 2007

[3] Mulyono, T., "Teknologi Beton”, Andi Offset, Yogyakarta, 2003,

[4] Tjokrodimuljo, K., "Teknologi Beton” Nafiri, Yogyakarta, 1996.

[5] Sihotang, Y dan Surbakti, B., "Analisa Lentur dan Eksperimental Serat Ijuk Aren (Arenae Pinnafa Merr) Pada Daerah Tarik Balok Beton Bertulang”, Departemen Teknik Sipil, Universitas Sumatera Utara, Medan, 2013,

[6] SNI 03-2834-1993 Tata Cara Pembuatan Rencana campuran Beton, Departemen Pekerjaan Umum, Jakarta.

[7] Dipohusodo, I., "Struktur Beton Bertulang", Gramedia Pustaka Utama, Jakarta, 1994

[8] SK SNI 03-1968-1990, Agregat Halus dan Kasar, Metode Pengujian Analisis Saringan. Yayasan LPMB, Jakarta.

[9] SNI 03-2493-2011 : Tata Cara Pembuatan dan Perawatan Benda Uji Dilaboratorium, Departemen Pekerjaan Umum, Jakarta.

[10] SNI 03-2491-2002 : Metode Pengujian Kuat Tarik Belah Beton, Departemen Pekerjaan Umum, Jakarta. 